\title{
Management Practices and Heifer Characteristics Associated with Early Lactation Somatic Cell Count of Belgian Dairy Heifers
}

\author{
S. De Vliegher, ${ }^{1}$ H. Laevens, ${ }^{2}$ H. W. Barkema, ${ }^{3}$ I. R. Dohoo, ${ }^{3}$ H. Stryhn, ${ }^{3}$ \\ G. Opsomer, ${ }^{1}$ and A. de Kruif ${ }^{1}$ \\ ${ }^{1}$ Department of Reproduction, Obstetrics and Herd Health, \\ Faculty of Veterinary Medicine, Ghent University, Merelbeke, Belgium \\ ${ }^{2}$ Coordination Centre for Veterinary Diagnostics, \\ Veterinary and Agrochemical Research Centre, Brussels, Belgium \\ ${ }^{3}$ Department of Health Management, Atlantic Veterinary College, \\ University of Prince Edward Island, Charlottetown, Canada
}

\section{ABSTRACT}

Associations between somatic cell counts (SCC) from heifers between 5 and $14 \mathrm{~d}$ in milk (DIM) and both herd-management practices and heifer characteristics were studied for 1912 heifers in 159 dairy herds in Flanders (Belgium). In higher-producing herds and in herds with an average calving age of heifers $>27 \mathrm{mo}$, SCC of heifers was lower than in less-producing herds or in herds with an average calving age $\leq 27 \mathrm{mo}$. Heifers raised in herds with a higher bulk-milk somatic cell count had higher SCC. In herds in which heifers calved on slatted floors, heifers had lower SCC compared with herds in which heifers calved on nonslatted floors. A significant difference in SCC was observed between provinces. At the heifer level, SCC decreased with increasing DIM. On average, heifers calving in April to June had higher SCC, compared with those calving in the other months of the year.

In the multilevel regression models, nearly all the variations of SCC resided at the heifer level, indicating that preventive measures against udder health problems in freshening dairy heifers should, in the short term, focus more on factors that vary between heifers than on factors that vary between herds. However, for the long term, the need to identify new, and to implement known, herd-level strategies is important.

(Key words: dairy heifer, multilevel, risk factor, somatic cell count)

Abbreviation key: BMSCC $=$ bulk milk SCC, HSCC $=$ herd geometric mean SCC, LnSCC = log-transformed SCC.

\section{INTRODUCTION}

Mastitis prevention programs, in general, focus on cows and not on heifers, although the latter are the

Received: January 31, 2003.

Accepted: September 15, 2003.

Corresponding author: S. De Vliegher; e-mail: Sarne.Devliegher@ UGent.be.

future of the dairy herd. The goal of having all heifers in the herd freshening with a healthy udder, capable of producing high-quality milk, is often not reached. Many studies have reported a high prevalence of IMI in nonlactating and freshly calved heifers, with mainly CNS and Staphylococcus aureus (Oliver and Mitchell, 1983; Trinidad et al., 1990; Pankey et al., 1991; Myllys, 1995; Fox et al., 1995; Nickerson et al., 1995). In addition, the incidence rate of clinical mastitis in heifers is very high during the first $14 \mathrm{~d}$ of lactation (Barkema et al., 1998a). Intramammary infections around parturition, either clinical or subclinical, will lead to considerable financial losses for the farmer and should, therefore, be avoided. Only a limited number of studies have looked at this problem, leaving many questions on how to prevent IMI in heifers pre-, peri-, and postpartum.

To reduce exposure to environmental pathogens, pregnant and peripartal heifers should be housed in a clean and dry environment (Shearer and Harmon, 1993). Poor hygiene of the calving area was associated with an increased prevalence of elevated SCC in heifers (Bareille et al., 2000). Supplementary preventive measures to control heifer mastitis include individual housing of preweaned calves to prevent suckling, fly control, supplementation of the diet with minerals, and segregation of pregnant heifers from dry cows (Shearer and Harmon, 1993). Frequent teat disinfection prior to parturition in primigravid dairy heifers did not improve udder health (Edinger et al., 2000; Waage et al., 2001). Vaccination of heifers was successful in reducing the incidence of Staphylococcus aureus IMI in one study (Giraudo et al., 1997) and not successful in another (Tenhagen et al., 2001). Treating pregnant heifers intramammarily with dry- or lactating-cow antibiotics reduced the prevalence of IMI at calving and increased milk production in their first lactation (Trinidad et al., 1990; Oliver et al., 1992; Owens et al., 1994; Owens et al., 2001) and is economically beneficial (Oliver et al., 2003). The use of antibiotics in heifers before calving should, however, be carefully promoted in the light of 
possible residue and resistance problems. Knowledge of more risk factors associated with high prevalence of IMI around parturition should be used to reach a more acceptable level of udder health in dairy heifers. Moreover, understanding at what level-herd versus individual heifer-preventive measures should be applied is essential in tackling the problem.

The objective of this study was to evaluate differences in herd-management practices and heifer characteristics associated with SCC of heifers in early lactation (between 5 and 14 DIM). The contribution of herd and heifer to the total variance of the SCC was assessed using multilevel, multivariable, linear-regression models.

\section{MATERIALS AND METHODS}

\section{Heifer Characteristics}

Four weekly milk recordings for 1999 and 2000 were available for all cows and heifers at least 5 DIM from the herds enrolled in the DHI program (Flemish Cattle Breeding Association, Oosterzele, Belgium) and included SCC, milk production at day of SCC measurement $(\mathrm{kg})$, breed, DIM, and date of measurement. The last variable was categorized into 4 calving seasons: January-March, April-June, July-September, and October-December. Somatic cell counts were measured based on composite milk samples collected from 2 successive milkings and were analyzed with the Fossomatic 5000 (Foss Electric, Hillerød, Denmark). To approximate the normal distribution, a natural logarithmic transformation of SCC (LnSCC) was used.

\section{Herd Selection and Management Practices}

Herds were selected from the 3287 dairy herds in Flanders (Belgium) participating in year 2000 in the DHI program that had at least one heifer for which the first SCC was measured between 5 and 14 DIM. From these herds, only those that had at least 10 such SCC were selected. A total of 254 herds matched this criterion, and 20 of those were dropped from the study because inspection of their data for the years 1999 and 2000 indicated that their SCC status had changed. A questionnaire was sent to the 234 dairy herds during spring 2001.

The questionnaire was tested and fine-tuned on 6 dairy herds not participating in the study. It consisted of 117 main questions concerning general management, milking and dry cow management, and management of calves and heifers, all concerning the year 2000. A summary is presented in Table 1.

All data were entered in an electronic spreadsheet program (Excel 2000, Microsoft Corporation) and were checked for typing and coding errors. Geometric mean SCC for all selected heifers in a herd (HSCC) were calculated for the 159 herds (68\% of 234) that returned the completed questionnaire. The overall data structure of the herds answering the questionnaire was as follows: SCC from 1912 heifers (lowest level of data hierarchy) were available, belonging to 159 herds (average of 12 heifers per herd, range 10 to 33 ) in 5 provinces (highest level of data hierarchy). Each province contained, on average, 32 herds (range 6 to 60 ).

\section{Statistical Analysis}

Prior to statistical analysis, observations were explored and checked for unlikely values. No data were excluded for this reason. The regression-model building process involved several steps, as presented in a flow chart (Figure 1). Initially, unconditional associations were tested between the continuous, dependent variable on herd level, HSCC, and all herd-management practices $(n=117$, Table 1$)$ as independent variables. An identical procedure was followed for LnSCC per heifer as dependent variable and 4 heifer characteristics-DIM, milk production, breed, and calving season-as independent variables. Independent samples $t$-tests, or one-way ANOVA for categorical independent variables and linear regression for continuous, independent variables were used. Statistical significance in this step was assessed at $P<0.15$. If necessary, reclassification was done for categorical variables, with some lowfrequency classes based on biological reasoning. Homogeneity of variances and deviances from normality were constantly checked using Levene statistics and Kolmogorov-Smirnoff test with Lilliefors correction. No problems were detected.

To detect multicollinearity, Pearson correlation coefficients were calculated among the significant $(n=28)$ management variables in a second step. The same was done among the 3 significant heifer characteristics. If 2 variables had a correlation coefficient $\geq 0.6$, only one was selected for further analysis, based on either the strongest association with the dependent variable or for biological reasons. Two herd-level variables, and no heifer-level variables, were discarded for this reason. The herd-level variable "calving season of heifers" was, although significant, not withheld for further analysis, as this variable was also available at heifer level (Tables $2,3,4)$.

In a third step, a multivariable linear-regression model was built with the 25 remaining management practice variables as independent variables, and with HSCC as the dependent variable. Nonsignificant variables were removed using backwards elimination at $P<$ 0.10 . Variance inflation factors were computed to detect 
Table 1. Overview of herd management practices during the year 2000, collected through a mailed questionnaire on 159 dairy herds in Flanders (Belgium).

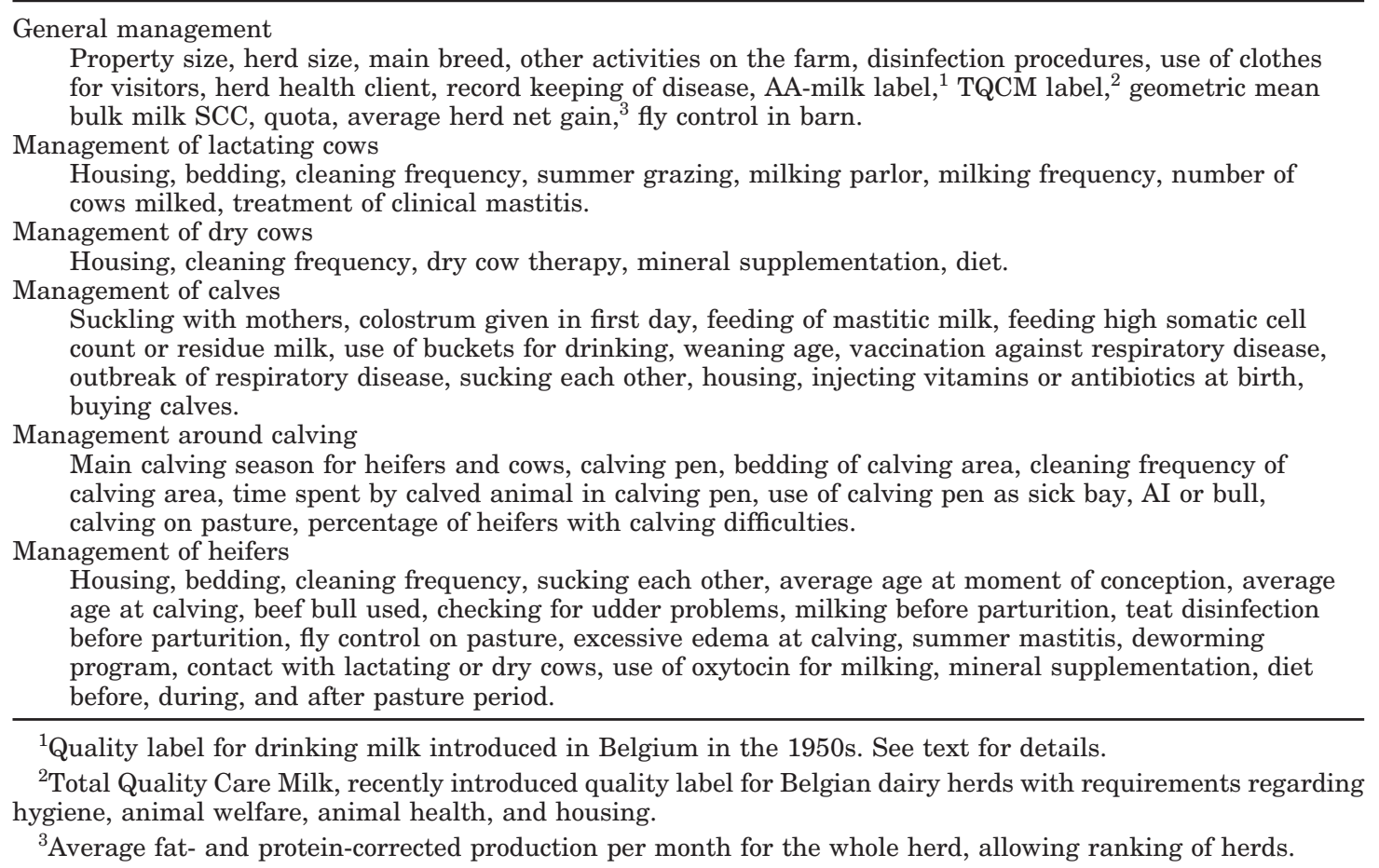

the presence of multicollinearity. Because all variance inflation factors were close to one and as a value $>10$ is taken as an indication of multicollinearity (Neter et al., 1996), it was concluded that the latter was not present. The third step reduced the number of significant management practices to 7 to be included in the multilevel, multivariable, linear-regression model; SPSS 10.0 for Windows (SPSS Inc., Chicago, IL) was used for all previous analyses.

In the final step, a multilevel model was fit for the continuous dependent variable LnSCC per heifer using the restricted generalized iterative least-squares algorithm in MLwiN 1.1 (Goldstein et al., 1998). All previously selected independent variables on the herd level $(\mathrm{n}=7)$ and on the heifer level $(\mathrm{n}=3)$ were added as fixed effects. As the herd-level variable "average herd net gain" and the heifer-level variable "production at the day of SCC measurement" were highly correlated, it was decided to leave the latter out of the analysis, as it was also correlated with DIM. To evaluate the proportion of variance occurring at the 3 levels of the data hierarchy, a 3-level null model (intercept only) was fit with "province," "herd," and "heifer" as random effects. In addition, the variance distribution was calculated for the 2-level null model (intercept only) by including "herd" and "heifer" as random effects. For further modeling, "province" was included as a fixed effect. The continuous, independent variables were centered by subtracting their overall mean, providing better interpretations and better numerical stability of estimates (Dohoo et al., 2001). All first-order interactions were tested and removed when nonsignificant (Wald's tests, $P>0.05$ ) were followed by nonsignificant main effects. The adequacy of the final model was tested by examining normal probability plots of residuals and plots of residuals versus predicted values to check whether the assumptions of normality and homogeneity of variance had been fulfilled. No patterns indicating heteroscedasticity were revealed.

\section{RESULTS}

\section{Description of the Data}

In 1999 and 2000, SCC between 5 and 14 DIM were available from 12,994 and 14,766 heifers from 3221 and 3287 herds, respectively. Geometric mean SCC for 1999 was 110,000 cells/mL (range 5000 to $18,817,000$ cells/ $\mathrm{mL}$ ). More details on the SCC of the year 1999 are presented elsewhere (De Vliegher et al., 2001). Geometric mean SCC of the 14,766 samples in 2000 was 104,000 cells $/ \mathrm{mL}$ (range 1000 to $25,088,000$ cell s/mL).

Geometric mean SCC for the 1912 heifers of the responding 159 herds was 92,000 cells/mL (range 1000 to $5,622,000$ cells $/ \mathrm{ml}$ ). The interquartile range was 163,000 cells $/ \mathrm{mL}$. At the herd level, HSCC ranged from 24,000 to 256,000 cells/mL. 


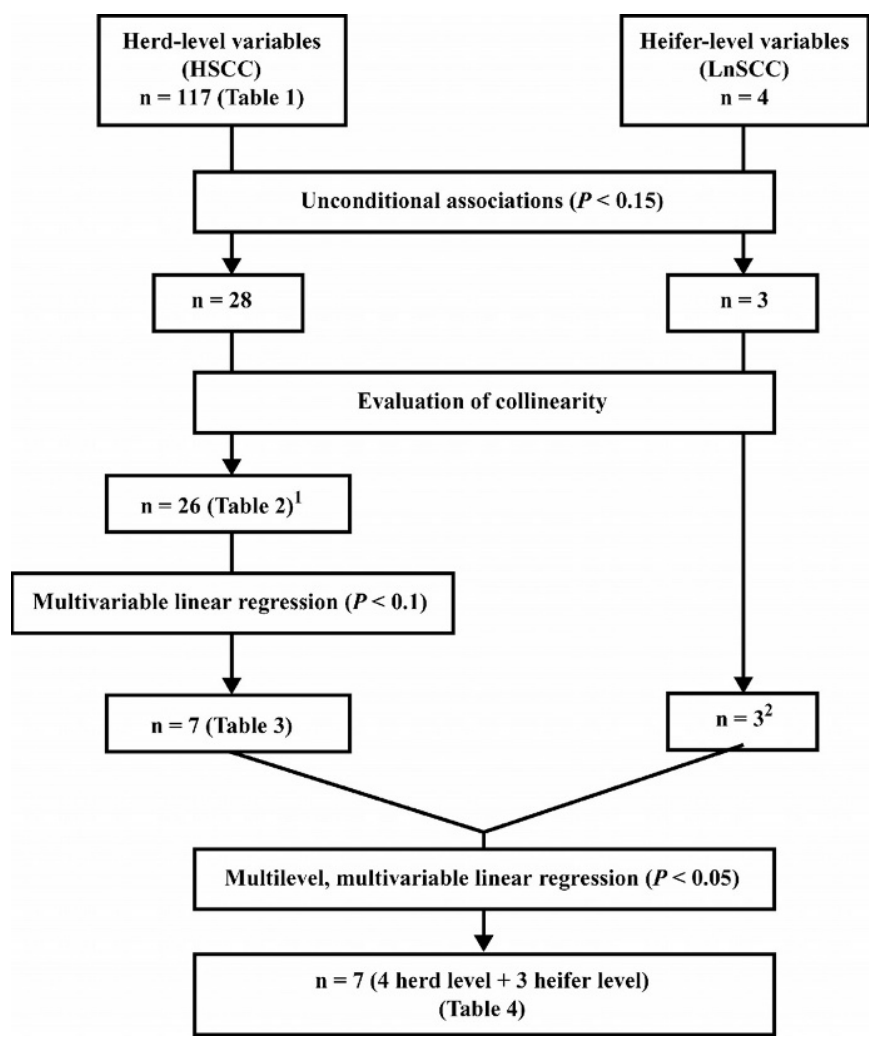

Figure 1. Flow chart of variable reduction through different steps in the statistical analysis. ${ }^{1}$ The herd level variable "calving season of heifers" was not withheld for further analysis, as this variable was also available at heifer level. ${ }^{2}$ The heifer level variable "production at the day of SCC measurement" was withdrawn as it was highly correlated with the herd level variable "average herd net gain" and DIM.

Of the 1912 heifers, 60\% were Black HolsteinFriesian, 27\% were Red Holstein, and 7\% were Red and White Holstein crossbreds. Average milk quota on the 159 herds was $537,067 \mathrm{~kg}$ of milk $( \pm 19,406)$, and the average milking herd consisted of 75 cows $( \pm 2.5)$ (range 25 to 230). Average bulk milk SCC (BMSCC) for 2000 was 175,000 cells/mL (range 73,000 to 334,000 cells/ $\mathrm{mL})$. Of the 159 farms, only $50 \%$ had dairy cows, $38 \%$ also had beef cows, and $8 \%$ also farmed pigs. Nearly $80 \%$ of all farms had an AA-milk label, a label that was introduced in Belgium in the 1950s to stimulate milk consumption. In addition to the official analyses that are conducted for all producers, specific AA-milk regulations provide for additional counts of coliforms twice a month. A number of other criteria (bacteria count, BMSCC) are also more stringent. By meeting these higher quality requirements, farmers are paid a premium price for their milk.

\section{Herd-Level Analysis}

In the first step of the analysis, a first reduction of all herd data, based on unconditional associations and highly correlated variables, revealed 26 herd-management practices significantly $(P<0.15)$ associated with HSCC (Table 2, 3, and 4). Multivariable linear-regression analysis resulted in a final model with 7 significant herd-practice variables at $P<0.1$ significance level (Table 5).

\section{Heifer-Level Analysis}

Somatic cell counts in early lactation showed a seasonal variation, with the highest values found during May to July (Figure 2). Somatic cell counts in early lactation progressively declined from 133,000 at 5 DIM to 70,000 cells $/ \mathrm{mL}$ at 14 DIM (Figure 3 ). Most of the 1912 SCC were measured in August to December ( $\mathrm{n}=$ 1431 or $74.8 \%$ ), with the highest proportion measured in September ( $\mathrm{n}=407$ or $21.3 \%)$ and lowest in July ( $\mathrm{n}=$ 21 or $1.1 \%$ ).

The univariable screening of the 4 heifer factors, using LnSCC for all individual heifers as dependent variable, led to 3 significant heifer characteristics: DIM, date at which SCC was measured (recoded to calving season), and production on day of SCC measurement ( $\mathrm{kg}$ of milk). All three variables were presented to the multilevel analysis.

\section{Multilevel Analysis}

The final multilevel model for the continuously distributed LnSCC is presented in Table 6. Four management practices and two heifer characteristics were significantly associated with LnSCC of heifers between 5 and 14 DIM. In higher-producing herds and in herds with an average calving age of heifers $>27 \mathrm{mo}$, SCC of heifers was lower than in less-producing herds or in herds with an average calving age $\leq 27 \mathrm{mo}$. Dairy heifers raised in herds with a higher BMSCC had higher LnSCC. In herds in which heifers were calved on slatted floors, LnSCC was lower than in herds in which heifers were calved on nonslatted floors. Province also remained a significant variable in the final model. At the heifer level, LnSCC decreased with increasing DIM. Heifers calving in April to June ran a higher risk of having elevated LnSCC opposed to the other 3 defined seasons of the year.

The variance components for the different models are presented in Table 7. In the 3-level null model, 1.6, 1.5, and $96.8 \%$ of the variation occurred at the province, herd, and heifer level, respectively, whereas in the 2level null model, 2.6 and $97.3 \%$ of the variation occurred at the herd and heifer level, respectively. These proportions changed slightly when adding the significant fixed effects. Of the total variance, 9.5\% was explained by the fixed effects $([1.696-1.535 / 1.696] * 100)$. 
Table 2. Significant $(P<0.15)$ unconditional associations between general herd management practices (categorical) and the geometric herd mean SCC of all heifers between five and 14 DIM per herd (HSCC, $\times$ 1000 cells/mL of milk) for 159 high yielding dairy herds in Flanders (Belgium).

\begin{tabular}{|c|c|c|c|}
\hline Categorical variables & $\mathrm{N}$ & HSCC & $P$ \\
\hline Province & & & $<0.001$ \\
\hline Antwerpen & 48 & 117 & \\
\hline Vlaams-Brabant & 6 & 138 & \\
\hline West-Vlaanderen & 23 & 110 & \\
\hline Oost-Vlaanderen & 60 & 88 & \\
\hline Limburg & 22 & 81 & \\
\hline Milking machine type & & & 0.135 \\
\hline Low line pipeline system & 113 & 98 & \\
\hline Other types & 46 & 109 & \\
\hline AA milk label ${ }^{1}$ & & & 0.062 \\
\hline Yes & 127 & 104 & \\
\hline No & 32 & 88 & \\
\hline Floor type of calving place or calving pen & & & 0.002 \\
\hline Nonslatted & 143 & 104 & \\
\hline Slatted & 16 & 70 & \\
\hline Time spent in calving pen after calving by cows and heifers & & & 0.097 \\
\hline Until just after calving/1 d & 143 & 99 & \\
\hline A few days & 14 & 119 & \\
\hline Calving pen used also as sick bay & & & 0.143 \\
\hline Yes & 77 & 106 & \\
\hline No separate calving pen on farm present & 81 & 96 & \\
\hline Type of barn & & & 0.073 \\
\hline Free stall with slatted floors & 139 & 99 & \\
\hline Other types & 20 & 117 & \\
\hline Floor bedding stanchion place or cubicle & & & 0.064 \\
\hline Straw or sawdust & 131 & 98 & \\
\hline Rubber or concrete & 28 & 115 & \\
\hline Mastitis treatment & & & 0.044 \\
\hline By farmer & 77 & 94 & \\
\hline Veterinarian involved & 82 & 108 & \\
\hline Fly problem during summer in the milking barn & & & 0.029 \\
\hline Similar to other years & 119 & 97 & \\
\hline More/less than other years & 40 & 114 & \\
\hline Injecting newborn calves & & & 0.062 \\
\hline With antibiotics only/both with vitamins and antibiotics/not injected & 148 & 100 & \\
\hline With vitamins only & 10 & 126 & \\
\hline
\end{tabular}

${ }^{1}$ Quality label for drinking milk introduced in Belgium in the 1950s. See text for details.

\section{DISCUSSION}

Milk somatic cell counting is an important instrument for monitoring udder health in lactating cows and is used worldwide as an indicator of subclinical mastitis (Laevens et al., 1998). Quarter-milk SCC is applicable as of day two postpartum to determine IMI (Barkema et al., 1999a). In the present study, SCC measured between 5 and 14 DIM were extracted from 4 weekly milk recordings to reflect udder health just after freshening. In culture-negative quarters, geometric mean SCC was as low as 42,000 cells $/ \mathrm{mL}$ at the sixth milking after calving (Barkema et al., 1999a), whereas 16 heifers that were culture negative during the whole first lactation had an average composite milk SCC of 49,000 cells/ $\mathrm{mL}$ during their first month of lactation (Laevens et al., 1997).

To identify management factors associated with elevated SCC, HSCC was calculated, giving an overall idea of udder health in periparturient heifers in a herd. A number of studies were able to find herd-management practices and heifer characteristics significantly associated with clinical mastitis (Waage et al., 1998, 2001; Myllys and Rautala, 1995). Not many studies, however, have focused on risk factors for subclinical mastitis in early postpartum heifers. Probably the first study to do so determined how the effect of location, season, stage of pregnancy, and herd influenced IMI in heifers (Fox et al., 1995). Two other studies focused on the issue using SCC of heifers (Østerås et al., 1997; Bareille et al., 2000).

The present study is, to our knowledge, the first one on a large number of dairy herds to study both management practices and some heifer characteristics that might influence the prevalence of mainly subclinical mastitis in recently freshened heifers. In addition, it was possible to estimate the distribution of variance on different levels (province, herd, and heifer), using multilevel modeling, a technique that takes into ac- 
Table 3. Significant $(P<0.15)$ unconditional associations between heifer management practices (categorical) and the geometric herd mean SCC of all heifers between 5 and 14 DIM per herd (HSCC, $\times 1000$ cells $/ \mathrm{mL}$ of milk) for 159 high yielding dairy herds in Flanders (Belgium).

\begin{tabular}{|c|c|c|c|}
\hline Categorical variables & $\mathrm{N}$ & HSCC & $P$ \\
\hline Heifers pregnant from & & & 0.023 \\
\hline AI & 70 & 92 & \\
\hline Bull, both AI and bull, bull after AI failed & 89 & 108 & \\
\hline Average age of heifers at calving & & & 0.117 \\
\hline Between 23 and $27 \mathrm{mo}$ & 122 & 104 & \\
\hline Older than $27 \mathrm{mo}$ & 37 & 89 & \\
\hline Clipping of heifers udders & & & 0.001 \\
\hline Around calving & 95 & 92 & \\
\hline A long period before calving/no clipping at all & 61 & 115 & \\
\hline Fly control in heifers on pasture & & & 0.010 \\
\hline One time pour-on/more than one time pour-on/using 2 ear tags & 109 & 95 & \\
\hline No fly control/only using one ear tag & 50 & 114 & \\
\hline Deworming of heifers & & & 0.047 \\
\hline All heifers & 130 & 98 & \\
\hline Only some heifers/no heifers & 26 & 117 & \\
\hline End term heifers kept with dry cows when not on pasture & & & 0.036 \\
\hline No & 100 & 106 & \\
\hline Yes & 57 & 91 & \\
\hline End term heifers supplemented with dry cow minerals & & & 0.111 \\
\hline No & 95 & 105 & \\
\hline Yes & 64 & 94 & \\
\hline $\begin{array}{l}\text { End term heifers during summer supplemented with something else } \\
\text { than hay, straw, sugar pulp, silage }\end{array}$ & & & 0.046 \\
\hline No & 144 & 102 & \\
\hline Yes & 12 & 77 & \\
\hline End term heifers supplemented with straw during fall/winter & & & 0.030 \\
\hline No & 119 & 105 & \\
\hline Yes & 35 & 87 & \\
\hline Calving season of heifers ${ }^{1}$ & & & 0.028 \\
\hline During autumn & 124 & 97 & \\
\hline During spring/during the whole year & 34 & 115 & \\
\hline
\end{tabular}

${ }^{1}$ Withdrawn for further analysis. See text for details.

count the hierarchical nature of data. As a result, it was possible to identify the level at which interventions will have the greatest impact on the outcome. Approximately $97 \%$ of the variance of LnSCC occurred at the heifer level based on the null models, with very small variance estimates at the province and/or herd level. All variation at the herd level was explained by including the significant herd level fixed effects, with all variation left in SCC at the heifer level. Another study on variance components of SCC also reported that herd only explained a small proportion of the variation in LnSCC, compared with cows nested within herds
(Schepers et al., 1997). The extreme distribution in the present study is most probably influenced by opting to work with SCC measured between 5 and 14 DIM, a period in which SCC vary more when compared to the rest of the lactation, and by opting for herds that had at least 10 SCC during 2000 . The latter procedure resulted in selecting slightly larger and better-producing dairy herds with better udder health: geometric mean SCC of the 1912 heifers was lower when compared to the value obtained from the 14,766 heifers from 2000 , of which they were a subset. This selection bias possibly influenced the variance distribution slightly, whereas

Table 4. Significant $(P<0.15)$ unconditional associations between management practices (continuous) and the geometric herd mean SCC of all heifers between 5 and 14 DIM per herd (HSCC, $\times 1000$ cells $/ \mathrm{mL}$ of milk) for 159 high yielding dairy herds in Flanders (Belgium).

\begin{tabular}{lllr}
\hline Continuous variables & $\beta$ & $\mathrm{SE}$ & $P$ \\
\hline Average herd net gain $^{1}(\times 10,000)$ & -0.001 & 0 & 0.067 \\
Geometric mean bulk milk SCC $(\times 1000$ cells/mL of milk) & 0.03 & 0.1 & $<0.001$ \\
Colostrum fed to newborn calves within first 24h (L) & 4.62 & 2.7 & 0.086 \\
Number of individual pens for calves & 0.61 & 0.4 & 0.132 \\
Percentage of heifers calving with difficulties & 0.75 & 0.4 & 0.044 \\
\hline
\end{tabular}

\footnotetext{
${ }^{1}$ Average fat- and protein-corrected production per month for the whole herd, allowing ranking of herds.
} 
Table 5. Final multivariable linear regression model based $(P<0.10)$ on the previously selected herd level variables for the geometric herd mean SCC of heifers between 5 and 14 DIM per herd (HSCC, $\times 1000$ cells/ $\mathrm{mL}$ of milk) as the dependent variable.

\begin{tabular}{|c|c|c|c|}
\hline Variable & $\beta$ & SE & $P$ \\
\hline Constant & 197.35 & 39.35 & $<0.001$ \\
\hline Province $^{1}$ & & & $<0.001$ \\
\hline Vlaams-Brabant & Ref. $^{3}$ & & \\
\hline Antwerpen & -44.29 & 18.52 & \\
\hline West-Vlaanderen & -50.37 & 19.03 & \\
\hline Oost-Vlaanderen & -72.95 & 18.11 & \\
\hline Limburg & -65.43 & 19.53 & \\
\hline Average herd net gain $(\times 10,000)^{2,4}$ & -0.001 & 0.00 & 0.002 \\
\hline Geometric mean bulk milk SCC $(\times 1000$ cells $/ \mathrm{mL}$ of milk $)$ & 0.25 & 0.06 & $<0.001$ \\
\hline Floor type of calving place or calving pen & & & 0.009 \\
\hline Nonslatted & Ref. $^{3}$ & & \\
\hline Slatted & -27.30 & 10.34 & \\
\hline Average age of heifers at calving & & & 0.008 \\
\hline Between 23 and $27 \mathrm{mo}$ & Ref. $^{3}$ & & \\
\hline Older than $27 \mathrm{mo}$ & -19.38 & 7.17 & \\
\hline Floor bedding stanchion place or cubicle & & & 0.022 \\
\hline Straw or sawdust & Ref. $^{3}$ & & \\
\hline Rubber or concrete & 18.51 & 8.01 & \\
\hline End term heifers fed straw during fall/winter & & & 0.067 \\
\hline No & Ref. $^{3}$ & & \\
\hline Yes & -13.68 & 7.41 & \\
\hline
\end{tabular}

${ }^{1}$ Forced into the model.

${ }^{2}$ Average fat- and protein-corrected production per month for the whole herd, allowing ranking of herds.

${ }^{3}$ Reference category.

${ }^{4}$ Withdrawn for further analysis. See text for details.

if the herds would have been selected randomly, more variation at the herd level could have been expected. The selection procedure used in this present study was, however, necessary to get a reliable impression of udder health in heifers in these herds.

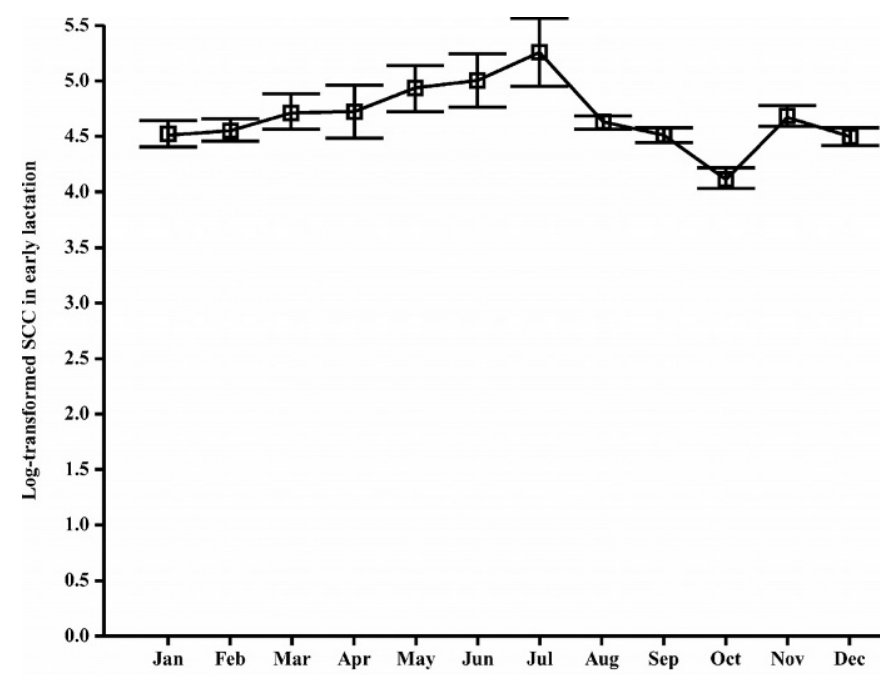

Figure 2. Log-transformed SCC $(\times 1000$ cells $/ \mathrm{mL})( \pm$ SEM $)$ between 5 and 14 DIM in 2000/mo from 1912 heifers from 159 dairy herds in Belgium.
Hence, as the vast majority of the variation of SCC resides at the heifer level, focusing on heifers, rather than on the herds, seems to be necessary when dealing with udder health in the short term. Lack of substantial effects at the herd level, though, should not be consid-

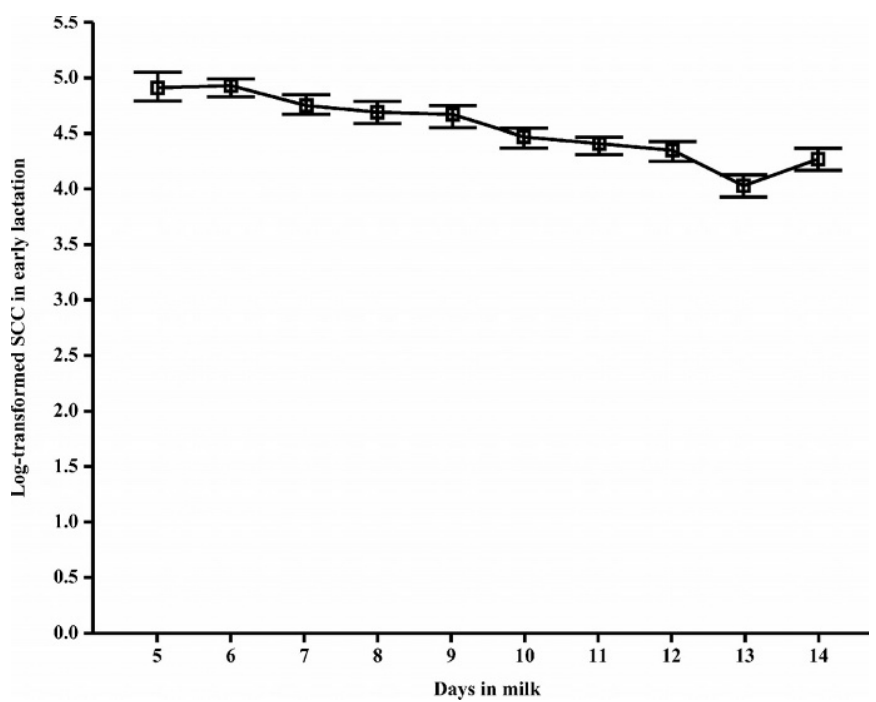

Figure 3. Log-transformed SCC $(\times 1000$ cells $/ \mathrm{mL})( \pm$ SEM $)$ in 2000 between 5 and 14 DIM in 2000, per DIM from 1912 heifers from 159 dairy herds in Belgium. 
Table 6. Significant $(P<0.05)$ herd and heifer level variables in the final multilevel linear model describing log-transformed SCC for 1805 heifers between 5 and 14 DIM (LnSCC) on 150 high-yielding dairy herds in Flanders (Belgium).

\begin{tabular}{|c|c|c|c|}
\hline Variable & $\beta$ & $\mathrm{SE}$ & $P$ \\
\hline Constant & 5.18 & 0.19 & $<0.001$ \\
\hline \multicolumn{4}{|l|}{ Province } \\
\hline Vlaams-Brabant & Ref. $^{5}$ & & $<0.001$ \\
\hline Antwerpen & -0.21 & 0.16 & \\
\hline West-Vlaanderen & -0.31 & 0.16 & \\
\hline Oost-Vlaanderen & -0.53 & 0.15 & \\
\hline Limburg & -0.46 & 0.17 & \\
\hline Average herd net gain $(\times 10,000)^{1,2,3}$ & -0.11 & 0.03 & $<0.001$ \\
\hline Geometric mean bulk milk SCC $(\times 100,000 \text { cells } / \mathrm{mL})^{1,2}$ & 0.23 & 0.06 & $<0.001$ \\
\hline Floor type of calving place or calving pen ${ }^{1}$ & & & 0.001 \\
\hline Nonslatted & Ref. $^{5}$ & & \\
\hline Slatted & -0.34 & 0.10 & \\
\hline Average age of heifers at calving ${ }^{1}$ & & & 0.014 \\
\hline Between 23 and 27 months & Ref. $^{5}$ & & \\
\hline Older than 27 months & -0.18 & 0.07 & \\
\hline Days in milk ${ }^{2,4}$ & -0.09 & 0.01 & $<0.001$ \\
\hline Calving date ${ }^{4}$ & & & 0.007 \\
\hline April - June & Ref. $^{5}$ & & \\
\hline January - March & -0.21 & 0.13 & \\
\hline July - September & -0.19 & 0.12 & \\
\hline October - December & -0.36 & 0.12 & \\
\hline
\end{tabular}

${ }^{1}$ Herd-level data (based on questionnaire data).

${ }^{2}$ Centered by subtracting the mean.

${ }^{3}$ Average fat- and protein-corrected production per month for the whole herd, allowing ranking of herds.

${ }^{4}$ Heifer-level data (extracted from milk recording lists).

${ }^{5}$ Reference category.

ered as proof that the improvement of udder health of dairy heifers is beyond the control of the farmer. This also appears from the fact that the herd-level fixed effects incorporated in the final model completely reduced the herd-level variance. But, although management practices of herds are thought to be of a major importance, a large variation seems to exist among heifers in response to an identical management. A possible explanation for the lack of variation at the herd level may be that strategies with a known positive effect on udder health in freshening dairy heifers are not yet implemented in Belgian dairy herds. Another reason could be that important herd-level factors have not yet been identified and have consequently not been implemented. Therefore, if effective preventive measures leading to substantially different SCC levels among herds would be adopted by some herds and not by others, more variation could be expected at the herd level.

Although statistically significant associations between SCC and both management practices and heifer characteristics were found in the present study, this does not prove causality. When studying large data sets with many variables, as in the present study, the probability of finding associations by chance increase substantially (Dohoo et al, 1997). In addition, the management ability of the farmer, influencing both udder

Table 7. Variance components at each level of 2 null models and the final model.

\begin{tabular}{llcl}
\hline & \multicolumn{3}{c}{ Variance estimate $\left(\mathrm{SE}^{1}-\%^{2}\right)$} \\
\cline { 2 - 4 } Data hierarchy & Three-level null model ${ }^{3}$ & Two-level null model & Two-level final model \\
\hline Province & $0.028(0.022-1.6)$ & - & - \\
Herd & $0.026(0.019-1.5)$ & $0.045(0.021-2.6)$ & $0.000(0.000-0.0)$ \\
Heifer & $1.651(0.056-96.8)$ & $1.651(0.050-97.3)$ & $1.535(0.053-100.0)$ \\
Total variance & 1.705 & 1.696 & 1.535 \\
\hline${ }^{1}$ Standard error of the variance estimate of the parameter. \\
${ }^{2}$ Variance proportion explained at the level of the data hierarchy. \\
${ }^{3}$ Model containing only the intercept with "province," "herd," and "heifer" as random effects. \\
${ }^{4}$ Model containing only the intercept with "herd" and "heifer" as random effects. \\
${ }^{5}$ Final model containing all fixed effects presented in Table 6, and "herd" and "heifer" as random effects.
\end{tabular}


health and other management practices, could be a confounder (Barkema et al., 1998b).

Significant differences in SCC between the 5 provinces in Flanders (Belgium) were seen in the present study. It was, however, not possible to explain this by the differences in management between herds. Surprisingly, the average BMSCC per province were not reflecting the same order in udder health, with the province Vlaams-Brabant having the lowest BMSCC $(155,000$ cells $/ \mathrm{mL})$ and the province West-Vlaanderen having the highest BMSCC (183,000 cells/mL).

Better-producing dairy herds had an overall better udder health in heifers in early lactation. To reach higher levels of milk production, these herds have to be well managed and, therefore, it is likely that they are more aware of the importance of heifers' udder health. Nevertheless, it seems that the herd-management practices associated with this higher production were not captured in the present study.

Higher BMSCC, reflecting the prevalence of subclinical mastitis in the lactating cows, was associated with a higher risk for individual heifers in a herd to have an elevated SCC. This indicates that heifers raised in herds with a higher prevalence of subclinical mastitis run higher risks to calve with IMI or to develop IMI within 1 to 2 wk postpartum, which agrees with the findings of another study (Bareille et al., 2000). On the other hand, high SCC of heifers could theoretically have increased the BMSCC of the particular herd, although only one SCC per heifer will not have had a huge impact on the BMSCC, as this was calculated as the geometric mean of all months in 2000 .

Calving of heifers on slatted floors, as opposed to calving on nonslatted floors, reduced the odds of heifers having a high SCC. Calving areas that have slatted floors will have drier bedding, as opposed to areas with completely closed floors. The same reasoning is behind the finding in another study in which incomplete slatted floors and alleys increased the incidence rate for Escherichia colii mastitis versus complete slatted floors and alleys (Barkema et al., 1999b). Providing a dry and clean environment to heifers and cows that are calving is important. A poor hygiene of the calving area was associated with an increased prevalence of elevated SCC in heifers (Bareille et al., 2000). Mucking out the calving area less often than once a month was a significant risk for clinical mastitis (Peeler et al., 2000). An increased incidence rate of $E$. coli mastitis, but not $S$. aureus mastitis, was found in herds in which there was no disinfection of the calving area after parturition (Elbers et al., 1998).

In herds in which heifers calved at an older age, heifers were at a reduced risk of a high SCC. This was a bit surprising, as older heifers will have been at risk of contracting IMI during a longer period. The current data were measured at the herd level, which makes conclusions on the individual heifer-level invalid. No conclusions can, therefore, be drawn regarding a possible dilution effect, as it is known that heifers calving at an older age tend to produce a bit more compared with younger heifers.

On the heifer level, 2 variables were significantly associated with SCC. Days in milk, as was expected in early lactation, was negatively correlated with SCC. A similar pattern was seen in other studies looking at composite milk samples (Dohoo, 1993; Laevens et al., 1997). Dilution due to an increasing production will most probably have contributed to this effect (Schepers et al., 1997), but this finding also suggests a spontaneous cure of IMI caused by CNS, and possibly by treatment of some heifers.

Calving season was also associated with SCC. Heifers calving in April to June had a higher risk of having elevated SCC, opposed to heifers calving in the other 3 defined seasons of the year. The fact that heifers have been in confined housing for a long period puts them at an increased risk of getting IMI, which is understandable. Myllys and Rautala (1995) identified 2 peak periods during which more heifers were treated for clinical mastitis, which is in accordance with the one peak in the SCC in our data. It should, however, be noted that the peak during July in our data for the 1912 heifers was only based on 21 values. In other studies, calving in late spring or summer was associated with an increased risk for clinical mastitis (Waage et al., 1998), and there was a significant association between the number of heifers with SCC $>200,000$ cells/mL and calving month, with May holding the highest, and December the lowest, risk versus September as reference (Østerås et al., 1997).

The significant heifer-level variables in the present study are limited in improving udder health in dairy heifers. Changing the calving season to the most favorable months is possible. As most of the variation was present at the heifer level, it would have been interesting to have more details on that level. Variables like calving problems of individual heifers, prepartum milk leakage, age at calving, and so on would have reduced the variance at that level. The present study was, however, designed mainly to focus on management practices, and although only 4 of these practices were significantly associated with SCC, they completely explained the variation at the herd level.

Some variables expected to be of importance and included in the questionnaire were not significant in the present study. From literature, for instance, it is known that fly control in heifers is very important in prevention of summer mastitis. Horn flies, in addition, are 
capable of spreading $S$. aureus-induced IMI to heifers (Owens et al., 1998). Another study revealed that heifers from herds using fly control had a lower prevalence of IMI than herds without fly control (Nickerson et al., 1995). In the present study, fly control resulted in lower SCC in the univariable analysis, but this variable disappeared in further multivariable analyses. Supplementing heifers with minerals was a managerial practice with an expected protective influence (Barkema et al., 1998b) on HSCC, and although a univariable association was present in our study, it was not present in the final model.

Although analyzing the data on a dichotomous scale based on a threshold reflecting a heifer to either be infected or not infected, was an option, it was decided to work on a continuous scale for several reasons. Dichotomizing the data would have reduced the power of the study to find significant variables. In addition, the discussion of which threshold was avoided and the use of a threshold could have resulted in biological fallacye.g., when using a cutoff of 200,000 cells/mL, classifying heifers with a SCC of 201,000 and 2,500,000 in the same group is debatable. Additionally, one of the aims of this study was to calculate the variance components, which is less straightforward in binary models (Dohoo et al., 2001). Finally, we believe that the actual SCC reflects better whether a heifer is infected in $0,1,2,3$, or 4 quarters, where a binary model would classify a heifer as either infected or not.

Based on the data used in the present study, it was not possible to decide whether a heifer suffered from an elevated SCC because of a prepartum infection (most likely to be subclinical) or because of an infection occurring during the first $2 \mathrm{wk}$ after calving (most likely to be clinical). Yet, it was possible to relate the significant management factors to pre- or postpartum infections. It is known that prevalence of IMI, mainly caused by minor pathogens and $S$. aureus at calving, is very high (Oliver and Mitchell, 1983; Trinidad et al., 1990; Pankey et al., 1991; Myllys, 1995; Fox et al., 1995; Nickerson et al., 1995), indicating that heifers were infected prior to calving. Prepartum management factors will therefore have influenced this phenomenon, and we believe that the variables "calving season" or "BMSCC" are most probably related to the aforementioned prepartum IMI. On the other hand, some of the heifers will have been infected in the first couple of days after calving, as we know from previous studies that incidence rate of mainly clinical mastitis is high during that period (Barkema et al., 1998a). We trust, therefore, that the variable "hygiene in the calving pen" is related to new infections in early lactation.

\section{CONCLUSIONS}

Multilevel regression modeling revealed some important herd-management practices and some heifer characteristics associated with SCC of dairy heifers in early lactation. Probably the most useful practice is reducing the BMSCC and thus the prevalence of subclinical mastitis in the herd, thereby reducing the risk of heifers getting infected prior to and at calving. In addition, more attention should go to periparturient hygiene and having as many heifers as possible calving during autumn, as this reduces the chance of having significant elevated SCC under Belgian conditions. Focusing more on differences between heifers than between herds seems to be important to control the problem of heifers calving with bad udder health in the short term, although the present data suggest both a lack of knowledge on the pathogenesis of IMI in heifers, and the lack of implementation of strategies with a known beneficial effect.

Conducting more studies combining bacteriological culture, SCC recording, registration of clinical cases, and recording of detailed heifer information and data on management practices on a large number of herds, are essential in tackling udder health problems in dairy heifers. In addition, the effect of an elevated SCC on production, udder health, and culling risk throughout the whole first lactation should be studied.

\section{ACKNOWLEDGMENTS}

The authors would like to thank E. De Mûelenaere and the Flemish Cattle Breeding Association (Oosterzele, Belgium) for providing us with the milk-recording lists and the Committees for Milk Quality for providing us with the BMSCC. All farmers that cooperated by sending back the questionnaire are gratefully acknowledged. Thanks must go to J. Valcour for the excellent assistance in data handling, to S. Willaert for the help in mailing the questionnaires, and to Intervet Belgium for supporting this study.

\section{REFERENCES}

Bareille, N., H. Seegers, M. B. Kiebre-Toe, F. Beaudeau, and C. Fourichon. 2000. Risk factors for elevated milk somatic cell counts during early lactation in dairy heifers. Pages 509-514 in Proc. 10th Int. Congr. on Anim. Hyg., Maastricht, The Netherlands.

Barkema, H. W., Y. H. Schukken, T. J. G. M. Lam, M. L. Beiboer, H. Wilmink, G. Benedictus, and A. Brand. 1998a. Incidence of clinical mastitis in dairy herds grouped in three categories by bulk milk somatic cell counts. J. Dairy Sci. 81:411-419.

Barkema, H. W., Y. H. Schukken, T. J. G. M. Lam, M. L. Beiboer, G. Benedictus, and A. Brand. 1998b. Management practices associated with low, medium, and high somatic cell counts in bulk milk. J. Dairy Sci. 81:1917-1927.

Barkema, H. W., H. Deluyker, Y. H. Schukken, and T. J. G. M. Lam. 1999a. Quarter-milk somatic cell count at calving and at the first six milkings after calving. Prev. Vet. Med. 38:1-9. 
Barkema, H. W., Y. H. Schukken, T. J. G. M. Lam, M. L. Beiboer, G. Benedictus, and A. Brand. 1999b. Management practices associated with the incidence rate of clinical mastitis. J. Dairy Sci. 82:1643-1654.

De Vliegher, S., H. Laevens, G. Opsomer, E. De Mûelenaere, and A. de Kruif. 2001. Somatic cell counts in dairy heifers during early lactation. Vlaams Diergeneeskd. Tijdschr. 70:212-215.

Dohoo, I. R. 1993. An evaluation of the validity of individual cow somatic cell counts from cows in early lactation. Prev. Vet. Med. 16:103-110.

Dohoo, I. R., C. Ducrot, C. Fourichon, A. Donald, D. Hurnik. 1997. An overview of techniques for dealing with large numbers of independent variables in epidemiologic studies. Prev. Vet. Med. 29:221-239.

Dohoo, I. R., E. Tillard, H. Stryhn, and B. Faye. 2001. The use of multilevel models to evaluate sources of variation in reproductive performance in dairy cattle in Reunion Island. Prev. Vet. Med. 50:127-144.

Edinger, D., B. A. Tenhagen, P. Kalbe, G. Klunder, B. Baumgartner, and W. Heuwieser. 2000. Effect of teat dipping with a germicide barrier teat dip in late gestation on intramammary infection and clinical mastitis during the first 5 days post-partum in primiparous cows. J. Vet. Med. A 47:463-468.

Elbers, A. R. W., J. D. Miltenburg, D. De Lange, A. P. P. Crauwels, H. W. Barkema, and Y. H. Schukken. 1998. Risk factors for clinical mastitis in a random sample of dairy herds from the southern part of The Netherlands. J. Dairy Sci. 81:420-426.

Fox, L. K., S. T. Chester, J. W. Hallberg, S. C. Nickerson, J. W. Pankey, and L. D. Weaver. 1995. Survey of intramammary infections in dairy heifers at breeding age and first parturition. J. Dairy Sci. 78:1619-1628

Giraudo, J. A., A. Calzolari, H. Rampone, A. Rampone, A. T. Giraudo, C. Bogni, A. Larriestra, and R. Nagel. 1997. Field trials of a vaccine against bovine mastitis. 1. Evaluation in heifers. J. Dairy Sci. 80:845-853.

Goldstein, H., J. Rasbach, I. Plewis, D. Draper, W. Browne, M. Yang, G. Woodhouse, and M. Healy. 1998. A User's Guide to MlwiN. Institute of Education, London, UK

Laevens, H., H. Deluyker, Y. H. Schukken, L. De Meulemeester, R. Vandermeersch, E. De Mûelenaere, and A. de Kruif. 1997. Influence of parity and stage of lactation on the somatic cell count in bacteriologically negative cows. J. Dairy Sci. 80:3219-3226.

Laevens, H., H. Deluyker, and A. de Kruif. 1998. Somatic cell count (scc) measurements: A diagnostic tool to detect mastitis. Pages 301-309 in Proc. 10th Int. Conf. on Prod. Dis. in Farm Animals, Utrecht, The Netherlands.

Myllys, V. 1995. Staphylococci in heifer mastitis before and after parturition. J. Dairy Res. 62:51-60.

Myllys, V., and H. Rautala. 1995. Characterization of clinical mastitis in primiparous heifers. J. Dairy Sci. 78:538-545.

Neter, J., M. H. Kutner, C. J. Nachtsheim, and W. Wasserman. 1996. Applied Linear Statistical Models. 4th ed. Irwin, London, UK.
Nickerson, S. C., W. E. Owens, and R. L. Boddie. 1995. Mastitis in dairy heifers: Initial studies on prevalence and control. J. Dairy Sci. 78:1607-1618.

Oliver, S. P., and B. A. Mitchell. 1983. Intramammary infections in primigravid heifers near parturition. J. Dairy Sci. 66:1180-1183.

Oliver, S. P., M. J. Lewis, B. E. Gillespie, and H. H. Dowlen. 1992. Influence of prepartum antibiotic therapy on intramammary infections in primigravid heifers during early lactation. J. Dairy Sci. 75:406-414.

Oliver, S. P., M. J. Lewis, B. E. Gillespie, H. H. Dowlen, E. C. Jaenicke, and R. K. Roberts. 2003. Prepartum antibiotic treatment of heifers: Milk production, milk quality and economic benefit. J. Dairy Sci. 86:1187-1193.

Østerås, O., R. B. Larssen, and E. Simensen. 1997. Environmental risk factors associated with mastitis in heifers. Pages 40-43 in Proc. 9th Int. Congr. Anim. Hyg., Helsinki, Finland.

Owens, W. E., S. C. Nickerson, P. J. Washburn, and C. H. Ray. 1994. Prepartum antibiotic therapy with a cephapirin dry-cow product against naturally occurring intramammary infections in heifers. J. Vet. Med. B 41:90-100.

Owens, W. E., S. P. Oliver, B. E. Gillespie, C. H. Ray, and S. C. Nickerson. 1998. Role of horn flies (Haematobia irritans) in Staphylococcus aureus-induced mastitis in dairy heifers. Am. J. Vet. Res. 59:1122-1124.

Owens, W. E., S. C. Nickerson, R. L. Boddie, G. M. Tomita, and C. H. Ray. 2001. Prevalence of mastitis in dairy heifers and effectiveness of antibiotic therapy. J. Dairy Sci. 84:814-817.

Pankey, J. W., P. A. Drechsler, and E. E. Wildman. 1991. Mastitis prevalence in primigravid heifers at parturition. J. Dairy Sci. 74:1550-1552.

Peeler, E. J., M. J. Green, J. L. Fitzpatrick, K. L. Morgan, and L. E. Green. 2000. Risk factors associated with clinical mastitis in low somatic cell count British dairy herds. J. Dairy Sci. 83:2464-2472.

Schepers, A. J., T. J. G. M. Lam, Y. H. Schukken, J. B. M. Wilmink, and W. J. A. Hanekamp. 1997. Estimation of variance components for somatic cell counts to determine thresholds for uninfected quarters. J. Dairy Sci. 80:1833-1840.

Shearer, J. K., and R. J. Harmon. 1993. Mastitis in heifers. Vet. Clin. North Am., Food Anim. Pract. 9:583-595.

Tenhagen, B. A., D. Edinger, B. Baumgartner, P. Kalbe, G. Klunder, and W. Heuwieser. 2001. Efficacy of a herd-specific vaccine against Staphylococcus aureus to prevent post-partum mastitis in dairy heifers. J. Vet. Med. A 48:601-607.

Trinidad, P., S. C. Nickerson, and T. K. Alley. 1990. Prevalence of intramammary infection and teat canal colonization in unbred and primigravid dairy heifers. J. Dairy Sci. 73:107-114.

Waage, S., S. Sviland, and S. A. Ødegaard. 1998. Identification of risk factors for clinical mastitis in dairy heifers. J. Dairy Sci. $81: 1275-1284$

Waage, S., S. A. Ødegaard, A. Lund, S. Brattgjerd, and T. Rothe. 2001. Case-control study of risk factors for clinical mastitis in postpartum dairy heifers. J. Dairy Sci. 84:392-399. 